\title{
Competitiveness Determinants of Moroccan Exports: Quantity-Based Analysis
}

\author{
Bilal Lotfi ${ }^{1} \&$ Mohamed Karim ${ }^{1}$ \\ ${ }^{1}$ EREMEFP, University of Mohammed V, Rabat, Morocco \\ Correspondence: Mohamed Karim, University of Mohammed V, Rabat, Morocco. Tel: 212-6618-3260. E-mail: \\ xmedkarimx@gmail.com
}

Received: April 9, 2016

Accepted: April 27, 2016

Online Published: June 25, 2016

doi:10.5539/ijef.v8n7p140

URL: http://dx.doi.org/10.5539/ijef.v8n7p140

\begin{abstract}
The term competitiveness is a relative concept whose perception changes with the level of conducted analysis (nation, sector, company). Thus, a variety of internal and external factors can have deep effects on the competitiveness of a given entity. This paper aims to evaluate the competitiveness of Moroccan exports by identifying the main determinants that explain their performance. This is particularly dealing with the impact of customs' tariff, the tariff of import, foreign demand, the share of the non-residents in the capital of domestic enterprises and the investment rate compared to the value of exporters.

Moreover, this paper presents a literature review on competitiveness and examines the main results of our econometric analysis regarding the determinants of export competitiveness applied to the top ten branches most exporters in Morocco. The gained results allow confirming the sensitivity of exports by branch to the situation of Morocco's main trading partner namely the European Union while emphasizing, quantitatively, on the role played by the investment effort undertaken by Moroccan exporting companies in improving the competitiveness of national exports.
\end{abstract}

Keywords: international competitiveness, trade, foreign exchange

\section{Introduction}

Following the signature of the Association Agreement with the European Union (AAEU) for the membership to the GATT agreements in 1987 and Uruguay Round (1984-1994), it is clear that Moroccan companies will face a highly increased competition. This situation will reduce the market shares already acquired and limit the possibilities of becoming competitive in the foreign market if the Moroccan economy does not improve its competitiveness. In this case, the capacity of Moroccan enterprises requires to better manage its resources, seeking the best investment and the development of their capacity of innovation that will be put to the test. These factors have a significance effect in improving the absorption capacity of the new technologies developed by competitors.

In order to evaluate the competitiveness of the Moroccan economy, this paper attempts to study the competitiveness of the most exporting industries in Morocco over the 1998-2014 period and to check whether the exporting companies in Morocco are sufficiently qualified to deal with a competition already looking fierce. This will, initially, be providing theoretical insight into the determinants of international competitiveness. Secondly, we propose a model of the determinants of structural competitiveness of the export industries. The final part will be devoted to an econometric analysis which identifies the factors likely to influence the international competitiveness of the Moroccan productive structure.

\section{Literature Review}

\subsection{Definition and Concept}

For a long time, the economic theory was interested in the exchange's economic determinants. In the exchange's traditional theory, the study of international exchange is based on different comparative advantages: a country exports a good which it holds a comparative advantage.

The concept of international competitiveness is frequently used as part of the analysis of macroeconomic performance of a given country. It compares, in fact, for a country and its trading partners, certain characteristic 
factors of the economy that provide elements of analysis on the development of international trade. This concept comprises primarily qualitative or not easily quantifiable factors.

The examination of the literature on the concept of competitiveness reveals the lack of a single and unique definition of the term competitiveness. Used in many empirical studies, the concept of competitiveness has not yet reached the accuracy level that is to expect "in economics" (Nezeys, 1993). It appears that the competitiveness varies with the level of the analysis (nation, sector, company), analyzed property (homogeneous or differentiated), and the objective of the analysis. Several authors emphasize that economic theory sets no static definition of competitiveness (Sharples, 1990; Ahearn et al., 1990). Definition of competitiveness probably due gain precision from a theoretical point of view as empirical. To clarify this point more, a myriad of quotations from economic literature is presented below.

Competitiveness is the ability to provide goods and services in time, at place and in form required by foreign buyers at price equal to or better than that of other potential suppliers while earning at least the opportunity cost of the resources that are used (Sharples \& Milham, 1990). According to Tyson (1992), competitiveness is the ability of a country to produce goods and services that meet the conditions of international competition, while allowing its citizens to enjoy both a growing and sustainable standard of living. The Organization for Economic Cooperation and Development (OECD) uses the following definition: the ability of companies, industries, regions, nations and supranational assemblies to generate, while being exposed to international competition, income levels and employment of factors relatively high (Hatzichronologou, 1996). The European Commission defines competitiveness as a steady increase in living standards in a country or region and a level of involuntary unemployment as low as possible. Indeed, for most economists, the competitiveness of the nation is a relevant concept that measured the ability of a country to achieve its economic growth target by getting involved in the international business. Consequently, the competitiveness can be defined as the ability to compete and compete successfully. An economy would be competitive if it is able to sell products that meet the requirements of the foreign demand (in terms of price, quality and quantity), while generating profits with which to develop. Given the multiple meanings associated with the term "competitiveness", we have to, from the beginning, locate the definition that we have retained in the economic literature. For this purpose, we use the following definition: Competitiveness is the production ability of a unit (company, national industry, etc.) to monopolize, profitably and sustainably, a large market share (Hazledine, 1993). This definition will serve as a starting point to establish a method execution for detailed quantitative analysis of competitiveness and its main determinants.

In Spite of this diversity of definitions, it should be noted the following two common aspects: (i) competitiveness is a relative concept, ie, the assessment of the competitiveness of a nation or a sector is usually made with respect to a similar entity; and (ii) competitiveness is not a static concept and is closely linked to the economic conditions of the country as well as international market conditions. So to endure competitive, an entity is required to follow a continuous process of adjustment in response to forces and of the factors in determining its competitive position on the market.

In general, a good measure of competitiveness should meet at least three essential criteria: First, cover all sectors that are exposed to competition, namely only traded or tradable goods; secondly, to include all markets where competition exists; and thirdly, be made from absolutely comparable international data. In practice, the available indicators generally have imperfections in these three criteria.

The neoclassical analysis incorporates the basic assumptions of the Ricardian model. But unlike Ricardo, its protagonists (Chakroun, 2002) explain that countries have access, worldwide, to the same types of production factors, substitutable for each other and to the same technologies. In this perspective, the technical change can only be conceived as a movement along the production functions in response to changes in relative prices: innovation is just a simple adaptation to the relative prices of factors of production that aim to reduce the costs.

Nowadays, the great upheavals of the economic system, globalization of production, research and development markets have resulted, in the $1980 \mathrm{~s}$, the proliferation of inter-company cooperation agreements and intensification of the internationalization phenomenon of firms. They therefore renewed discussions about the ability of developing countries to make better use of the technology boom of the industrialized countries, and to develop competitive advantages in the global market.

To sum up, even if unanimity is not required on the concept of competitiveness, it is generally perceived as the ability of countries to successfully integrate into the global economy. By measuring competitiveness, even in a well-defined conceptual framework is the result of many compromises in the choice of criteria and objectives, taking into account all available data. In addition, many technical considerations must be taken into account in the construction of competitiveness indicators for which there is no single solution, even in theory. 


\subsection{Competitiveness Measurement}

The international competitiveness of a country is measured by its results or its factors. In the first case, analysts use market share indicators and in the second case the indicators of cost and price.

The cost indicators compare the export cost indices of a country to its competitors or those of its partners. The relative stability in the cost of labor compared to other production costs make the indicator of the relative unit cost of labor $\left(C_{m}\right)$, shown below, the most used indicator.

$$
C_{m}=\left(\begin{array}{lll}
e & w & l / Q
\end{array}\right) /\left(w^{*} l * / Q^{*}\right)=e\left(w / w^{*}\right)(q * / q)
$$

With $q=Q / l$ : the apparent labor productivity; $l$ : defined as level of employment; $w$ : wage rate; $e$ : nominal exchange rates, and we noted by "* " the exogenous variables. A decrease of $C_{m}$ or other cost indicator represents an improvement of the external competitive position of the studied economy. This decrease reflects increased costs outside compared to internal costs.

The market share indicators measure the level of exports at constant prices for a country $\mathrm{i}$ over a period: $\mathrm{Pm}_{\mathrm{it}}=$ $\bar{P}\left(\mathrm{Q}_{\mathrm{t}}-\mathrm{Q}_{\mathrm{t}-\mathrm{j}}\right)$; or it measure the level of its exports compared to a reference zone $\mathrm{R}: \mathrm{Pm}_{\mathrm{iR}}=\left(\mathrm{P}_{\mathrm{i}} \mathrm{Q}_{\mathrm{i}}\right) /\left(\mathrm{P}_{\mathrm{i}} \mathrm{Q}_{\mathrm{i}}+\mathrm{P}_{\mathrm{R}} \mathrm{Q}_{\mathrm{R}}\right)$. An increase in $\mathrm{Pm}_{\mathrm{iR}}$ or $\mathrm{Pm}_{\mathrm{it}}$ is interpreted as an improvement in external competitiveness. This increase reflects an increase in market share of country i compared to the reference zone or in the period of study.

Market share or more accurately the growth of the market share has been used as a performance indicator in many empirical studies (Larson \& Rask, 1992). However, contrary to the measures relating to production costs and those that are related to the productivity of factors, this indicator captures both the factors of non-price competitiveness than price competitiveness factors affecting the performance of a given product. Therefore, it is considered as a measure of the outcome of competitiveness. Moreover, despite its widespread use, this indicator can be insufficient. Indeed, this indicator cannot distinguish between an increase in market share due to improvement of performance of that due to an export subsidy, or between a decrease in the share due to poor performance from that due to a quota.

\subsection{Determinants of International Competitiveness}

Becoming internationally competitive is considered an objective of public policy. The primary objectives of international competitiveness can explain many steps taken by governments: the reduction of the deficit, reduction customs barriers and the reductions of social safety net.

For economists, the concept of international competitiveness must be purged of its mercantilist origins and associated to concepts of increasing productivity and living standards. Among the factors that affect competitiveness and consequently export performance, several authors have specifically investigated the role played by the following factors:

- The productivity: improvements made in terms of organization of labor, changes in the quality of production factors, a better knowledge of production processes and the efficiency of resource allocation can positively affect the productivity. In this context, productivity gains appear to be a critical determinant of the competitiveness of a given country (Parienty, 2013).

- Customs tariffs: A Customs Tariff duty is the simplest of trade policy measures. It is a tax levied on the occasion of the import of goods. This variable are traditionally used as a source of income for governments but their true purpose is none other than protecting particular economic sectors. From the perspective of the exporter, the augmentation of the customs duties can be considered like a transportation cost. Thus, the tariff increases the price of goods in the importing country and the decreases in the exporting country. Consequently, consumers are subject to losses in the importing country and gain in the exporting country. As for producers, they share gains in importing countries and losses in the exporting countries.

- Exchange rate: Macroeconomic theory considers a decline in the real exchange rate (a fall in the relative price of tradables in terms of nontradables goods) boost exports and limit the effect of external constraints. From this angle, the devaluation is a powerful factor that can promote the development and international competitiveness (Boltho, 1998).

- Global demand: To fully benefit from opportunities offered by trade liberalization, it has been shown that a country have interest to choose wisely its foreign partners. However, given the size of the market and product quality required for export, developing countries will gain more if they trade with industrial countries than trading with poor countries. The effort of developing countries to valorize their exports and thus ameliorate their competitiveness, allows them to access to the market of developed countries. Thus, at every increases of global demand, especially in developed countries, increases the export, in developing countries, of products which seem 
competitive with those in rich countries.

- Foreign participation: the share of foreign capital in the Moroccan companies is considered a significant source of funding in addition to its role in transfer of technology and know-how. The investment effort constitute a determining factor in the creation of dynamic comparative advantage, capturing economies of scale and increasing returns (Mzoughi, 2000). The investment also helps to stimulate technological innovation and improve the productivity of factors. For this purpose, it is a key determinant of competitiveness and the long-term growth of an economy. The accumulation of capital then offers companies the possibility to fully take profit from the opportunities in the global market, caused by additional global demand or a favorable diversion of international conditions. In this perspective, we can consider that high competitiveness is a dynamic sustainably and sustained accumulation of capital (Toujas-Bernate, 1991). Its insufficiency denotes an inability of domestic producers to meet domestic and foreign demand. It results, in addition, in a relative loss of export market shares and in a systematic deterioration of external position (Chakroun, 2002).

\section{Methodology}

\subsection{Data}

Examining the evolution of the performance of all branches is obviously tricky. This paper will focus on the competitiveness of the Moroccan economy internationally by analyzing the evolution of the turnover of national exportation. The unavailability of sufficient data to carry out this study by product has thwarted us to be limited to an aggregate level by branch. We will try to conduct the study with a sample of the most export sectors, covering a significant part of the turnover of Moroccan exportation.

We will calculate the export share of each branch in the total exports belonging to the period of study. We note that throughout the period of our study, the first ten branches covering almost $75 \%$ of total Moroccan exports, therefore we will include in our sample any branch occupying in a year of the study period rank among the top ten branches most exporters. Therefore, we get the sample composed by order the following branches:

D24 branch (Note 1): Chemical Industry (Note 2);

D31 branch: Manufacturing machines and Power Devices;

D34 branch: Automotive Industry;

D18 branch: Industry of Clothing and Furs;

D23 branch: Refining of Petroleum and Other Energy Products;

D15 branch: Food Industry;

D17 branch: Textile Industry;

C01 branch: Extraction of Coal, Lignite, Peat;

A00 branch: Agriculture, Forestry, Hunting;

D27 branch: Metallurgy.

\subsection{Model}

Analysis Recent economic literature on the determinants of export uses the following specific econometric model:

$$
E X P O=\alpha_{0}+\alpha_{1} E R+\alpha_{2} \text { Tariff }+\alpha_{3} G D+\alpha_{4} F O R E+\alpha_{5} \operatorname{In} v+\mu
$$

We have:

- EXPO: Export;

- ER: Exchange Rate of exporting country;

- Tariff: Customs Tariff of the foreign country where the exported product is intended;

- GD: Global demand of the foreign countries in products, in other words: their imports;

- FORE: share of non-residents in the capital of domestic enterprises;

- Inv: investment rate (investment ratio, added value);

$-\mu$ : Error term.

The study covers the period between 1998-2014. In the case of Moroccan exports, the empirical analysis of the competitiveness of the Moroccan economy will be based on the following variables: 
- EXPO: Moroccan exports by industries; source: Exchange Office;

- ER: Exchange Rate of Morocco represented by the weighted average of the currencies of major trading partners. The weighting system is the share of these countries in foreign trade of the country. The selected partners are the EU, the USA, Japan, England, Canada...

- Tariff: European Union tariffs. Source of tariffs is the World Bank.

- GD-EU: Imports of the main trading partner of Morocco (MAD value), namely the European Union, because foreign trade with the European Union alone constitute more than 66 percent of foreign trade of Morocco (Ministry of Plan, 2012). Data collected from the World Bank. These were collected in Million Dollar then were transformed into Dirham based on the rate (\$ / MAD) of the Exchange Office;

- FORE: Foreign participation in the capital of Moroccan manufacturing firms (in \%), by branch; Data collected from the Ministry of Industry, Trade, Investment and the Digital Economy;

- Inv: the rate of investment by branch, it is calculated as a ratio: investment relative to the added value.

\section{Results}

The results of our calculations (following table) are not always in line with expectations of theoretical development. In this model, the variables shown above are expressed in logarithmic form so that their coefficients can be readily interpreted as elasticities.

Table 1. Determinants of competitiveness of the Moroccan economy

\begin{tabular}{|c|c|c|c|c|c|c|c|}
\hline Branch & $\log (\mathrm{ER})$ & $\log$ (Tariff) & $\log ($ GD-UE $)$ & $\log (\mathrm{FORE})$ & $\log ($ Inv $)$ & $\mathrm{R}^{2}$ & DW \\
\hline \multirow[t]{2}{*}{ Branch D24 } & 0.35 & 0.46 & 0.72 & & 0.14 & 1 & 1.67 \\
\hline & $(0.031)$ & $(0.020)$ & $(0.035)$ & & $(0.079)$ & & \\
\hline \multirow[t]{2}{*}{ Branch D31 } & 2.56 & 0.47 & 0.43 & -0.32 & 0.91 & 1 & 1.80 \\
\hline & (0.048) & $(0.017)$ & $(0.071)$ & $(0.062)$ & $(0.029)$ & & \\
\hline \multirow[t]{2}{*}{ Branch D34 } & & -2.17 & 0.46 & 2.12 & 0.42 & 0.60 & 1.30 \\
\hline & & $(0.001)$ & $(0.089)$ & $(0.023)$ & $(0.018)$ & & \\
\hline \multirow[t]{2}{*}{ Branch D18 } & 0.40 & -1.47 & 0.62 & 0.08 & -0.37 & 1 & 1.10 \\
\hline & $(0.023)$ & $(0.028)$ & $(0.032)$ & $(0.047)$ & $(0.010)$ & & \\
\hline \multirow[t]{2}{*}{ Branch D23 } & & -7.52 & & 1.39 & $0.91 * *$ & 0.90 & 2.50 \\
\hline & & $(0.079)$ & & $(0.035)$ & $(0.037)$ & & \\
\hline \multirow[t]{2}{*}{ Branch D15 } & & -0.78 & 0.97 & & 0.24 & 0.92 & 3.40 \\
\hline & & $(0.049)$ & $(0.021)$ & & $(0.085)$ & & \\
\hline \multirow[t]{2}{*}{ Branch D17 } & 0.24 & -1.68 & 0.23 & 0.62 & 0.37 & 0.82 & 1.42 \\
\hline & $(0.063)$ & $(0.017)$ & $(0.013)$ & $(0.044)$ & (0.059) & & \\
\hline \multirow[t]{2}{*}{ Branch C01 } & & -3.79 & & 1.13 & $0.67 * *$ & 0.79 & 2.90 \\
\hline & & $(0.035)$ & & (0.038) & $(0.022)$ & & \\
\hline \multirow[t]{2}{*}{ Branch A00 } & & -2.56 & 0.74 & & & 0.95 & 1.37 \\
\hline & & $(0.043)$ & $(0.040)$ & & & & \\
\hline \multirow[t]{2}{*}{ D27 } & 0.36 & -0.51 & 0.39 & -0.32 & 0.54 & 1 & 1.13 \\
\hline & $(0.078)$ & $(0.050)$ & $(0.091)$ & $(0.061)$ & $(0.024)$ & & \\
\hline
\end{tabular}

Source. Authors' calculations.

The results of the econometric estimation are consistent with economic theory, to the exclusion of tariff elasticity (in the case of Chemical Industry), of foreign participation in the capital of Moroccan enterprises (in the case of Chemical Industry, Machinery Manufacturing industry and Electrical Devices and Metallurgy) and of the investment rate (in the case of Industry of clothing and Furs).

The long-term effect of economic openness of the European Union, measured in this paper by tariffs, should have a positive effect on the competitiveness of Moroccan exporting entities. This hypothesis are confirmed in most branches. Therefore, for any relief European customs barrier of 10\%, follows an increase in exports of $75.2 \%$ (resp. 1.6\%, 4.7\%, 21.7\%, 14.7\%, 7.8\%, $16.8 \% 37.9 \% 25.6 \%$ and 5.1\%) for the Refining Oil and Other energy Products branch (resp. Chemical Industry branch, Machinery Manufacture Electric Appliances branch, Automotive Industry branch clothing and Furs branch Food Industry, Textile Industry branch, branch of Extraction of coal, Lignite, Peat, branch Agriculture, Forestry, Hunting and Metallurgy branch). As for the sector 
of the chemical industry, it reacts negatively to any lowering of European Union tariffs: any decrease it by $10 \%$ leads to a decrease in exports of this branch of the order of $4.6 \%$.

Furthermore, the European Union is the main trade partner of Morocco. Its share in Moroccan exports represents $60 \%$ to $70 \%$ (Ministry of Plan, 2012). This leaves exports sensitive to changes in demand for the Union in Moroccan products. For every $10 \%$ increase in demand for the European Union increases the volume of exports of around 9.7\% (resp. 7.2\%, 4.3\%, 4.6\%, 6.2\%, 2.3\%, 7.4\% and 3.9\%) for the Food Industry branch (resp. Chemical Industry branch, branch of Machinery Manufacture Electric devices, branch of Automotive Industry branch of clothing and Furs, Textile Industry branch, Agriculture branch, Forestry, Hunting and Metallurgy branch).

The effort utilized by the branches of the Moroccan economy in investment seems decisive in strengthening the ability of exporters to compete and to win significant shares of the market share. So an increase of $10 \%$ of the investment effort in the long run leads to an increase in export volume of $1.4 \%$ for the Chemical Industry Branch, 9.1\% for the Branch of Manufacturing Machinery, Electric Appliances, $4.2 \%$ for the automotive industry, 2.4\% for the Food industry sector, $9.1 \%$ for the Refining Division of Oil and Other Products of energy, $6.7 \%$ for the branch of Mining coal, Lignite, Peat and 5.7\% for the Metallurgy branch. This reflects the importance of the self-financing capacity of domestic enterprises in the consolidation of the autonomy and independence of the foreign trade (M.Chakroun, 2002). It also demonstrates that optimum utilization of production capacity is likely to meet the world demand and to take full advantage of developments in the international situation.

In the contrary, for the rest of the branches, the negative effect of an increase in the investment effort, can assume a significant improvement in the added value in these branches, followed by an improvement in exports. The flow of foreign capital also participates significantly in the international competitiveness of the Moroccan economy. The coefficient associated therewith is high in the branch of the automotive industry: a $10 \%$ increase in net flows of foreign direct investment leads to a net increase of $21.2 \%$ of the volume of its exports, while it only leads to an increase of $0.8 \%$ of exports of the branch of the clothing industry and Furs.

For other branches, namely, branch of Manufacturing Machinery \& Electric Equipment Branch and Metallurgy, the elasticity of exports with respect to foreign participation is negative. Any increase in $10 \%$ of the Moroccan exchange rate, equivalent to a devaluation of the Dirham, leads to an improvement in exports of $25.6 \%$ (resp. $3.5 \%, 4.0 \%, 2.4 \%$ and 3.6\%) among the branches of Machinery Manufacturing \& Electric devices (resp. Chemical Industry, Industry Branch of clothing and Furs, Branch of Textile Industry and branch of Metallurgy).

The non-significance of variables denoting foreign participation to explain the value of exports of the chemicals branch \& parachemistry can be attributed to the fact that the bulk of foreign trade is handled by the OCP Group (foreign participation may explain the evolution of exports since the OCP is owned entirely by the state).

\section{Conclusion}

This paper, through a simplified model of export performance of top ten export sectors of the Moroccan economy, led to distinguish between several effects: firstly the effect of the European demand for domestic goods and customs tariffs and the effect of increased foreign participation in the capital of Moroccan companies. It is also clear from our analysis that the impact of the improvement in the investment rate on the performance of export sectors.

The econometric results on Moroccan manufacturing branches, widely exposed to international competition, used to highlight the sensitivity of exports of these branches to the economic situation of the trading partner of Morocco namely the European Union, and its significant impact outdoor performances. The creation of the Euro Mediterranean Zone can be a salutary solution, but its success requires a substantial European Union aid and major foreign direct investment (FDI) inflows to bridge the gap between the two shores of the Mediterranean. To take full profit of these inflows, Morocco should conduct a policy in terms of training and educating its people so that the technology diffusion can fully fulfill its role in improving the productivity via the FDI. This policy should go in a new conception of international competitiveness of the Moroccan economy in general, and particularly in manufacturing sector for a long-term perspective. For this reason, the state must encourage the private investment and scientific research within the framework of mutual cooperation between the two poles university-industry, which would strengthen the competitiveness of industrial products in the international market (Chakroun, 2002, p. 14) in the long term.

It will require all stakeholders in the economic and political scene accelerate the pace of change that must be completed before the end of the transition period, otherwise it will be too late for many of the Moroccan companies that will, perhaps, put the key under the door. Other questions can be raised further: 
- What currency policy should be actually implemented by the Moroccan government to advance the competitiveness of the manufacturing sector?

- The reforms and the different policies to renew and modernize the Moroccan productive structure, have they had the expected results?

- Etc...

\section{References}

Bertelet, N. S., François, K., \& Ludovic, F. (2013). Real Exchange Rate, Foreign Direct Investments and Competitiveness of Cameroon Pineapple In European Union. Asian-African Journal of Economics and Econometrics, 13(2), 177-187. $\quad$ Retrieved from http://www.serialsjournals.com/serialjournalmanager/pdf/1436354796.pdf

Boltho, A. (1998). Convergence, Competitiveness and the Exchange Rate. In N. Crafts, \& G. Toniolo (Eds.), Post War European Economic Growth (pp. 107-30).

Chakroun, M. (2002). Les déterminants de la compétitivité internationale du secteur manufacturier Tunisien: Un modèle. Retrieved from http://www.institut-europlace.com

CNUCED. (1994). World Investment Report, 35(140), 946-947.

Commission européenne. (2009). Rapport sur la compétitivité européenne 2008. Commission européenne, Bruxelles.

Debonneuil, M., \& Fontagné, L. (2003). Compétitivité. la documentation française, Paris. Retrieved from http://www.ladocumentationfrancaise.fr/var/storage/rapports-publics/034000199.pdf

Dimelis, S., \& Louri, H. (2004). Foreign Direct Investment and Technology Spillovers: Which Firms Really Benefit? Review of World Economics, 140(2), 230-253. http://dx.doi.org/10.1007/BF02663647

Diouf, M. (2008). L'aide pour le commerce et l'insertion dans l'économie mondiale: Le cas de la convention de Lomé. Université Paris Dauphine, Thèse Pour L'Obtention Du Titre De Docteur En Sciences ECONOMIQUE. Retrieved from https://basepub.dauphine.fr/bitstream/handle/123456789/191/These_MamadouDiouf.pdf?sequence=1

Djimasra, N. (2009). Efficacité technique, productivité et compétitivité producteurs de coton. Retrieved from https://tel.archives-ouvertes.fr/tel-00482828

Ethier, W. J. (1982). National and International Returns to Scale in the Modern Theory of International Trade. The American Economic Review, 72(3), 389-405. Retrieved from http://www2.econ.iastate.edu/classes/econ655/Lapan/Readings/Ethier\%20NationalandInternationalReturnst oScale.pdf

Faye, K. D. (2004). Analyse des Déterminants de la Compétitivité Internationale Sénégalaise. Mémoire de DEA en Economie Internationale, Universite Cheikh Anta Diop De Dakar. Retrieved from http://www.beep.ird.fr/collect/ptci/index/assoc/HASH0177.dir/2004-Faye-Analyse\%20des\%20determinants .pdf

Fontagné, L. (1999). Foreign Direct Investment and International Trade: Complements or Substitutes? OECD Science, Technology and Industry Working Papers, No. 1999/03, OECD Publishing. http://dx.doi.org/10.1787/788565713012

Fontagné, L., \& Pajot, M. (2002). Relationships between Trade and FDI Flows within two Panels of US and French Industries. In R. E. Lipsey, \& J. L. Mucchielli (Eds.), Multinational Firms and Impacts on Employment, Trade and Technology (pp. 43-83). London : Routledge.

Gannagé, E., \& Bourguinat, H. (1985). Théories de l'investissement direct étranger. Paris, London, Genève: Editions Economica. Retrieved from http://bibliotheque.insee.net/index.php?lvl=notice_display\&id=111638

Gehrke, C. (2014). Ricardo's Discovery of Comparative Advantage Revisited. Graz Economics Papers - GEP. Retrieved from http://ideas.repec.org/s/grz/wpaper.html

Hatzichronoglou, T. (1996). Globalisation et compétitivité: Indicateurs pertinents pour l'analyse. Documents de travail de la Direction de la science, de la technologie et de l'industrie, 1996/5, Éditions OCDE, Organisation de coopération et de développement économiques, Paris, France.

Hazledine, T. (1993). New Zealand Trade Patterns and Policy. Australian Economic Review, 26(4), 23-27. http://dx.doi.org/10.1111/j.1467-8462.1993.tb00807.x 
Humphrey, J., \& Schmitz, H. (2013). How does insertion in global value chains affect upgrading in industrial clusters? Institute of Development Studies, University of Sussex, Brighton BN1 9RE, UK. Retrieved from http://www.uwi.edu/ccfc/wp-content/uploads/2013/11/How-Does-Insertion-in-GVCs-Affect-Upgrading-in-I ndustrial-Clusters.pdf

Joël, T. B. (1991). L'Allemagne, premier exportateur industriel mondial. In Economie et Statistique (pp. 109-117). $\quad$ France-Allemagne. Retrieved from http://www.persee.fr/doc/estat_0336-1454_1991_num_246_1_6301

Khamassi-El Efrit, F., \& Hassainya, J. (2001). Analyse de la compétitivité des entreprises et des produits agro-alimentaires: Pertinence et apports de l'approche filière. In M. Padilla, B. Saïd, J. Hassainya, \& P. Le Grusse (Eds.), Les filières et marchés du lait et dérivés en Méditerranée: Etat des lieux, problématique et méthodologie pour la recherche. Retrieved from http://ressources.ciheam.org/om/pdf/b32/CI011673.pdf

Kokko, A. (1994). Technology, Market Characteristics and Spillovers. Journal of development Economics, (43). Retrieved from http://down.cenet.org.cn/upfile/39/2008731154131174.pdf

Krugman, P. (1981). Trade, Accumulation, and Uneven Development. Journal of Development Economics. North-Holland Publishing Company. http://www.eco.uc3m.es/ desmet/trade/KrugmanJDE1981.pdf

Krugman, P. R. (1981). Intraindustry Specialization and the Gains from Trade. The Journal of Political Economy, 89(5), 959-973. http://dx.doi.org/10.1086/261015

Krugman, P., \& Obstfeld, M. (2001). Economie Internationale. Bruxelles, DeBoek éditeur.

Lachaal, L. (2001). La competitivité: Concepts, définitions et applications. In A. Laajimi, \& L. Arfa (Eds.), Le futur des échanges agro-alimentaires dans le bassin méditerranéen: Les enjeux de la mondialisation et les défis de la compétitivité. Zaragoza: CIHEAM, 2001. p. 29-36 (Cahiers Options Méditerranéennes; n. 57). Retrieved

from https://www.researchgate.net/publication/236893372_La_Competitivite_Concepts_Definitions_et_Applicat ions

Lall, S. (1995). Emploi et Investissements Etrangers: Quelles Orientations pour les PED? Revue Internationale du Travail, 134(4-5), 573-599.

Larson, D. W., \& Rask, N. (1992). Changing competitiveness in world soybean markets. Agribusiness, 8(1), 79-91. http://dx.doi.org/10.1002/1520-6297(199201)8:1<79::AID-AGR2720080107>3.0.CO;2-6

Latruffe, L. (2010). Competitiveness, Productivity and Efficiency in the Agricultural and Agri-Food Sectors. OECD Food, Agriculture and Fisheries Papers, No. 30, OECD Publishing. http://dx.doi.org/10.1787/5km91nkdt6d6-en

Muller, A. (1995). La politique industrielle de Singapour. Problèmes Economiques, ${ }^{\circ} 2419$, avril.

Mzoughi, N. (2000). Performances Commerciales d'une Economie avec Changement de Structure: Le Cas de la Tunisie. Communication pour le colloque du GDR "Economie et Finance Internationales Quantitatives", 23-24 juin, Tunis.

Nezeys, B. (1993). La compétitivité internationale. Publication: Economica, Paris.

OMC. (1996). Rapport Annuel de l'OMC. Le Commerce et l'IDE, 1.

Pamies-Sumner, S. (2005). Peut-on Mieux Comprendre L'évolution Récente des Exportations Françaises? Une Analyse Économétrique. Ministere De L'Economie Des Finances Et De L'Industrie Française, Direction Générale Du Trésor et de la Politique Economique, Document de travail. Retrieved from https://www.tresor.economie.gouv.fr/File/331598

Parienty, A. (2013). Les déterminants de la compétitivité. Alternatives Economiques, (329). Retrieved from http://s182403251.onlinehome.fr/spip.php?article91

Ricardo, D. (1984). Des Principes de l'Economie Politique et de l'Impôt. Réédition de l'original de 1817, Flamarion, Paris. Retrieved from http://classiques.uqac.ca/classiques/ricardo_david/principes_eco_pol/ricardo_principes_1.pdf

Rivera-Batiz, L. A., \& Romer, P. (1991). Economic Integration and Endegeneous Growth. The Quarterly Journal of Economics, 106(2), 531-555. http://dx.doi.org/10.2307/2937946

Romer, P. (1990). Endogenous Technological Change. Journal of Political Economy, 71-102. http://dx.doi.org/10.1086/261725 
Romer, P. M. (1987). Growth Based on Increasing Returns Due to Specialization. Papers and the Proceedings of the Ninety-Ninth Annual Meeting of the American Economic Association. The American Economic Review, 77(2), 56-62. Retrieved from http://www.development.wne.uw.edu.pl/uploads/Courses/gtac_romer_87.pdf

Wang, J., \& Blömstrom, M. (1992). Foreign Investment and Technology Transfer. European Economic Review, (36). Retrieved from http://www.nber.org/papers/w2958.pdf

\section{Notes}

Note 1. Code of branch in Nomenclature National Accounting (NNA).

Note 2. Label of the branch NNA.

\section{Copyrights}

Copyright for this article is retained by the author(s), with first publication rights granted to the journal.

This is an open-access article distributed under the terms and conditions of the Creative Commons Attribution license (http://creativecommons.org/licenses/by/3.0/). 